\title{
Ethnoliguistic Study of Local Wisdom in Ex-Residency of Surakarta
}

\author{
Wakit Abdullah \\ Universitas Sebelas Maret Surakarta \\ Email: abdullahwakit@yahoo.com
}

\begin{abstract}
This study discusses "the local wisdom summarized in the proverbs of the Javanese community in Ex-residency of Surakarta". The purposes of this study are to describe (1) the background of the local wisdom as summarize in the proverbs of the Javanese community in Ex-residency of Surakarta, (2) to elaborate further reasons and specific times the people in Exresidency of Surakarta employ the Javanese proverbs that summarize the local wisdom, and (3) explain the cultural meanings resided in the Javanese proverbs. This study employed ethnographic methods framed by the ethnolinguistic study to find the cultural meanings. Data and the data sources are categorized into primary and secondary data; the data collection method is done through the observation-participation and in-depth interview techniques; data analysis employed the ethnoscience model which underwent 12-phases of advanced research stages (of taxonomic, componential and domain analyses) to find the cultural themes; validity of the data is attested with the triangulation techniques (the triangulation of data, methods, researcher, and theory). The results encompassed (1) background of the local wisdom summarized in the Javanese proverbs expressed by the Javanese community in Ex-residency of Surakarta influenced by the cultural factors, the Javanese language, aesthetical, ethical, social, economical, political, and geographical factors; (2) the community in ExSurakarta expressed the Javanese proverb that summarizes local wisdom, the demands of fidelity to the culture is inevitable, media that facilitates the growth of the Javanese language, aesthetical and ethical motivations, social conditions, economical motivation, political media which show the geographical background; and (3) the cultural meaning of the Javanese proverbs which summarize the local wisdom of the community in Ex-residency of Surakarta, all of which are to show the courtesy, avoid direct confrontation, the proverbs also indicate levels of the beauty of the language use, nationalism, foster cooperation, develop the intellect.
\end{abstract}

Keywords: ethnolinguistic, ex-residency of Surakarta, Javanese proverb, local wisdom

\section{INTRODUCTION}

Javanese language as a product of the Javanese community reflects the highest of its culture. The nature and behavior of the Javanese community are visible through the language or language activities. The Javanese cultural development enriches the Javanese language in all the aspects. Paribahasa or Javanese proverbs, as a form of language use may reflect the nature and personality of the users. Moreover, the meaningful expression of indirectness is a reflection of Javanese culture which is a very typical for the Javanese community. Instead, the Javanese culture will continue to be symbiotic mutualism with the language.

Javanese proverbs as language use of a complex category are still commonly found in 
common and daily life of the Javanese community in Ex-residency of Surakarta. Philosophical approach of understandings to the Javanese proverbs based on the finding data indicated the life wisdom of the Javanese ancestors. This phenomenon literally becomes evidence that the community still maintains sense of belonging and willingness to preserve their cultural heritages. The Javanese proverbs as part of the idiomatic aspects of the Javanese language are not merely verbal expressions intended to demonstrate the beauty of the language. However, they are considered to be part of the ways that the Javanese people in Ex-Surakarta to express long experience and wisdom of the Javanese people's lives. Among other types of the employed Javanese proverbs are (1) sapa salah bakal seleh 'who goes wrong, therefore will be defeated'. (2) aja dumeh 'do not be arrogant', (3) ana dina ana upa literally means there is a day there is a rice, whereas culturally it means 'stay excited and optimistic in building a life motivation'; (4) rukun agawe santosa, crah agawe bubrah literally means 'harmony leads to be strong, bickering leads to be damaging', while culturally meant in harmony create a powerful and divorced disarray may cause weak even destroyed; 5) sapa nandur bakal ngundhuh 'Who do will reap the results'.

In literary context, the verbal expressions of the Javanese proverbs which summarize the local wisdom of the daily life of the Javanese people are encoded in the literary expressions. While in the context of the values of universal life is empirical objectives, i.e. the messages resided in proverbs are significantly matched with the present contexts, both in Ex-residency of Surakarta and in the framework of the nation and state of Indonesia's diversity. Therefore, the benefits of rethinking the disclosed values of local wisdom in the Javanese proverbs enable the reinforcement of identity and inspiration for the future generations. The values of everyday life reflected from the Javanese proverbs summarize various dimensions of the Javanese lives which are not limited by space and time (universal, universality). Therefore, being deemed to be part of the Javanese community, enable these individuals a resistance against selfishness, collective arrogance, and cultural separatism, political, economic, and territorial greediness. The
Javanese proverbs expressing life optimism; these individual characteristics are easily subverted by the instant mindset; which is instructed to avoid emotion that easily burns out and widens up because of a small, trivial and resolvable case. Such a diplomacy becomes an important choice as well as deemed to be a shortcut to avoid the future outrageous reactions and regretful; having a strong and steely fighting spirit and unyielding struggle for the sake of the upright, the strength and selfidentity of the Indonesian nationality, etc.

Conceptually, the idea of local wisdom is understood as the efforts of using various ways by people of certain community to address the issue with a rightly and properly manners (Ahimsa, 1997; Wakit, 2013). Furthermore, local wisdom (local genius) (Quaritch Wales in Poespowardojo, 1986: 30; Rahyono, 2009: 7-9) as "the sum of the cultural characteristics the which the vast majority of a people have in common as a result of Reviews their experiences in early life". This concept contains fundamental thoughts about (1) the characteristics of the culture, (2) a group of people as the owner of the culture, and (3) life experience that produces such cultural traits.

According Mahsun (2005: 81) adapted from the Journal of Indonesian Linguistics, mentioning many ways to uncover the cultural behavior (of indigenous) society, one of them is through viewing the language use. The evidence on the language use to uncover the behavioral aspects of the speakers is thus a possible thing. Additionally, the idea structure of the language use has to do with people of community's thinking, a thought by Sapir-Whorf (1956), and reformulated by Clark and Clark (1977: 557) confirmed that the language use has an influence on the way people think. The concept of linguistic relativity means encode the way language and cognitive categories of culture affect the way people think, so that speakers of different languages think and behave differently because it (Aggs-lingual, October, 28, 2016). Whorf(1956 Robert M. Krauss and Chi-Yue Chiu) assumed that the use of language to encode the results of experience in the parallelism between linguistic and cognitive structures. Consequently, every language combine metaphysics or naive conception of reality and the speaker of the real different languages have different mental image of 
the same state of affairs.

According to Dove (1985: xv) the role of traditional culture is closely linked with the fundamental process of social, economic and ecological society. Moreover, traditional culture is a dynamic one, which in this case, cannot be separated from the influence of the local leadership traits (Uffortd, ed., 1988).

Ethnolinguistics as elaborated by Foley (1997) is a branch of linguistics that examines the relationship from language to language to express the meanings subsequently appropriate with its cultural contexts. Among relevant studies discussed the Javanese language and culture in Ex-residency of Surakarta are the studies done by Wakit Abdullah (1999) on the Javanese language in Surakarta, the results stated that the Javanese language in Ex-Surakarta, although within one living area, the influence on the center of languages and cultures of Java in Surakarta still indicates a dialectal variations which characterized by both phonetic and lexical variations; Wakit Abdullah (2001) studied the Elements of Nepotism Summarized in the Javanese proverbs expressed by the community in Surakarta, the results concluded that there are the Javanese proverbs that reflect the nature of the Javanese nepotistic sense and values in addressing the situation and in running for a government; Wakit Abdullah (2009 and 2010) on the Javanese Language in Relation to the Javanese Community's Conducts in Surakarta (An Ethnolinguistic Perspective; Sri Supiyarno (2011) studied the values of humanism, the results reveal that the Javanese proverbs summarize the life value particularly the life wisdom of the Javanese ancestors; Ni Wayan Sartini (2009) in an article entitled "Menggali Nilai Kearifan Lokal Budaya Jawa Lewat Ungkapan (Bebasan, Saloka, Dan Paribasa)". By using data from saloka, bebasan and paribasa, her study discussed such cultural values reflected in the linguistic expressions. Accordingly, there are five idiomatic expressions in Javanese culture such as (1) expressions which are describe behavior and ideology; (b) expressions which are related with strong will; (3) expressions which are describe relationship human and God, (4) relationship between humans, (5) expressions which reflect improper behavior. In addition, Christiana Dwi Wardhana (2012) studied the Javanese language in Relation to Economic Potential of Klitikan Market in Surakarta (An Ethnolinguistic Study).

Therefore, problems related the Javanese proverbs which engage the local knowledge are among the factors underlying the use of the Javanese proverbs expressed by the community in Ex-residency of Surakarta as part of the local wisdom, why do the community in Ex-Surakarta use Javanese proverbs that summarize the local wisdom, how cultural meanings resided in the Javanese proverbs summarize the local wisdom of the Javanese community in Ex-residency of Surakarta.

Based on these things, there should be research and inventory of expression, paribasan Java language in the Ex-residency of Surakarta. This study is important because the values of the local culture or local wisdom manifested in the proverbs can be used as guidelines for ethics, philosophy of life, tradition, philosophy, and thus capable of sustaining life balance within this heterogeneous country. In addition, understanding the factors as well as the motivation behind the disclosure of Javanese proverb in various social and political domains as a form of speaking wisely put the Javanese as a high society personality. Based on the above background, this study discusses the values, several factors and motivations on the use of paribasa the Javanese language as one of the local wisdom of Javanese culture.

\section{METHOD}

Methodologically, this study adopts a descriptive-qualitative research method which applied the ethnographic methods and followed by the ethnoscience model of analysis (Spradley, 1997: 19) and linguistic methods if necessary. The sources and research data covered both primary and secondary forms of verbal expressions (Javanese proverbs) and nonverbal expressions (context, cultural events) of which the local knowledge is resided in out of the contexts of the Javanese community's language and culture in Ex-residency of Surakarta. The purposive and snowball samplings are used as a technique of collecting the data, these processes would continue until getting a complete-comprehensible data (Sutopo, 2006: 45-46). As this study focused in 
providing explanation to the Javanese proverbs used by the Javanese community living in the Exresidency of Surakarta, the sample populations took 21 key informants under specific and minimum of five criteria ${ }^{1}$. Among the informants were taken from 5 regencies (Wonogiri, Sragen, Karanganyar, Klaten, which represents each district. Techniques of data collection employed (1) participant observation (Spradley, 1997: xvi), (2) in-depthinterviewing technique with selected informants to interpret the Javanese proverbs expressed by the Javanese community in Ex-residency of Surakarta. Furthermore, the ethnoscience model of analysis (taxonomic, componential, and domain analyses) to relevantly find the themes of culture (Spradley, 1997: 120). Validity of the data were measured up with triangulation techniques (triangulation), key informant reviews and member check (Sutopo, 2006: 92). Results of the analyses are presented in both formal and informal methods.

\section{FINDINGS AND DISCUSSION}

\section{Proverbs and Javanese Proverbs}

Meider (1985: 119) defines proverbs as "short sentences which contain society's generally understood wisdom, truth, morals, and traditional views in the form of metaphorical words, easily memorized and passed down from generation to generation". Meanwhile, according to the view of a linguist named N.R. Norrick (1985: 78) proverbs is a form of conversation, a deductive sayings (instructive) or common meaningful suggestions, freedom of expressions through using the figurative meaning". Furthermore, proverbs contains very rich of historical experience of the public expressing their ideas related work, life and culture. The uses of proverbs in a right and appropriate manners and time of everyday communication shows a unique characteristic of the speech society.

Indonesia is widely known as a nation of about 300 tribes and each has its own cultural identity (Koentjaraningrat in Warnaen, 2001: 5). Every tribe has its particular proverbs that reflect local values. The phrase used is usually impressive, with a broad meaning and content wise. Proverb widely used in the daily lives of people in the first period and passed down from generation to generation, because it is considered as the easiest way for them to give advice, warning or satire. And vice versa, the contents are easily caught by the parties advised. When investigated the letter and spirit contained therein, so many materials that can be drawn from the historical, social and meaning of their lives at that time.

In Javanese culture, proverbs are widely used to convey messages or certain values. Those values are very noble and great and inherited. These proverbs are used to provide advice, guidance or warning. Each of the use proverbs and the contextual situations are motivated by a number of factors. Based on the finding data, the results of this study can be described in the following paragraphs.

Factors underlying the use of the proverbs by the Javanese community in Surakarta which summarize the local wisdom. The factors may include:

1. Cultural Factors. Amongst the finding data, it is found that the cultural factors have become one of the triggering spirits of the Javanese community in Ex-Surakarta to faithfully use and express the Javanese proverbs in everyday life, both in the formal and informal atmospheres to meet the needs of "communication" hereditary from time to times. For example, on certain traditional events such as childbearing, wedding as well as death to funeral processions, the rituals are customarily followed by the acts of cleaning local village, rice planting season and harvest management, feast-day rituals, among other related spells, related to personifying the magical figures, ancestors, addressing the painful sufferings, life expectancy, kinship, peak inner satisfaction, divinity, and related to harmony, etc. In sum, as a linguistic expression Javanese proverb relates to everyday life processions (childbearing, wedding, death to funeral, planting rice to harvesting, circumcision, etc.).

2. Linguistic Factors. Language as a medium to communicate things related to the mindset (concerning the positive ideas), a life-view (related to the philosophical understandings toward life as illuminated by religious teachings, upheld the traditional positive values, and other positive life guidelines) 
and the worldviews (physically and mentally, land-sea, top-down) to be one of the reasons why in the daily life of Javanese community in Ex-residency communicate the inner motivations to which consciously view the Javanese proverb as a media to explain pivotal messages. Furthermore, the proverbs itself are intentionally expressed to avoid the possibility of impolite belief or sense, which might offend other people's feelings, or easily deemed oneself to a lower-value degree, as well as to avoid feeling shallow, and the like. Figuratively and pragmatically to meet the related matters of aesthetics (speaking beautifully) and ethics (maintaining good sense and manners), logical (both the listener and reader should have selfencouragement to the positive messages resided in them), as well as expressing the Javanese proverbs as a way to place oneself in a right and noble position in their social lives.

3. Aesthetical Factors. Aesthetics in a sense that the Javanese community expresses the proverbs both in formal and informal life which are pragmatically expressed to obtain additional value to a more beautiful (aesthetic) way of expressing the Javanese language according to the use of dictions, redactions, expressions, and emotional effects. In the one hand, communicating a local language by way of expressing proverbs that reflect a sense of beauty could help the interlocutors to avoid mismanagement in a communication due to breaking self-sensitivity which triggers one's emotional state. In addition to expressing the proverbs could be perceived as things motivating the inward awareness, harmonious expressions (artwork material, physical, communication, self-positioning, etc.) of the interlocutors.

4. Ethical Factors. Javanese proverb is part of the option to smartly address with potential use of polite communication. The local community realize that the use of the Javanese proverbs in their own daily communication is to poster politeness in expressing certain message as well as a sound act of communication through ethics and modeled by figurative language to avoid offensive communication due to direct use of language, control the interlocutors' emotions, avoid speaking bluntly which cause to unpleasant evaluation. Therefore, as a kind of linguistic expression, the Javanese proverbs summarize local wisdom on ethics as a social life's guidance incorporating to the things perceived inward sense related to where, when and about what reflections to the attitude of saluting, insulting, tolerant, proportionate manners, etc.) of the interlocutors.

5. Social factors. Socially within the life of the community, there is a view which is maintained that expressing the Javanese proverbs, in essence, is a realization of promoting the spirit of togetherness for the benefit of tranquil and harmonious life of the society. As it has elaborated in advance that the benefits of language which express the Javanese proverbs are the means of building and maintaining the spirit of cooperation (communication can be properly and harmoniously undergone for it is not principally built on an offensive way of expression) and be able to develop wisdom (both interlocutors, the speakers and listeners can be benefited from pondering the messages resided in the Javanese proverbs). Therefore, as linguistic expression Javanese proverbs summarize local wisdom pertaining with any social event and matters related to the encountering public spheres (social harmony or disharmony, social backwardness or advancement, or being further from the main city, etc.).

6. Economical Factors. Traditions on expressing the Javanese language by way of proverbs engage a number of traditional events (ritual acts of cleaning local village, wedding, circumcision, death and funeral processions, etc.), there come to be a group of intelligent people who acquire qualifications related to the ability of utilizing proverbs for the benefits of their lives. As a result, this group of people could earn money from their traditional lifeskill or ability to ngrengga basa "create a beautiful language' by leveraging the Javanese proverb to occupy a number of professional careers and jobs such as to be a Javanese Master of Ceremony (MC) (pangendhali wara, paniti laksana etc.). Therefore, as a linguistic expression Javanese proverb summarize a local 
knowledge related to the economic situation that engaged both the social or personal achievements (sufficiency, insufficiency, unsuccessful crop, side jobs, other sources of income, etc.)

7. Political factors. The existence of Javanese proverbs amidst the society can be wellmaintained because they dealt with the ongoing political atmosphere, which sharpened, and referred to sensitive things, uncompromising and frightening. As part of the linguistic expressions, Javanese proverbs summarize local wisdom which are referred to the ongoing political situations, numerous events and atmospheres of dealing with suffered things in life beings of the interlocutors (troubled, restless, confused, scared, bored, revenge, hatred, etc.).

8. Geographical Factors. Geographically, it is found that the use of the Javanese proverbs indicates a position wherein the Javanese community undergoes their life. Whether in the lowlands or in the mountains, in office, or as an ordinary person, as an educator or as an employee, as a parent or as a child, being in an atmosphere of formal or informal, in the village or in the city, and various other identifications. On expressing the Javanese proverbs, people normally relate the previous activities and conditions to particular themes occurred at any specific and ongoing time. However, expressing the Javanese proverbs generally influenced by the previously established proverbs or sayings from the local language center and culture which become the main option, because these proverbs are aesthetically deemed to beautifulness and more ethical use of language and have been widely adopted and understood according to the degrees of politeness and the practitioners of that language.

In regard of those data, it is understood that the use of proverbs in context enables us to understand the unknown side of the 'story', how different aspects of life were and are reflected in people's mind, what is considered important in a culture's perception of its micro world and thus remembered and transmitted, how are the 'others' perceived, how is the 'anger' and fear of the difficult times articulated? These are important questions to address the anthropological linguistic phenomenon of proverbs. Thus, there are underlying factors stimulating people, as mention above, in specific context the Javanese community in Ex-residency of Surakarta, and people of Java in wider scoop.

In proverbs, implicit element of cultural system of society with regard to the values, worldview, guidelines and rules become a reference for members of the society. Being part of the oral tradition, the development of proverbs is greatly influenced by the changes taking place in the supporting community. Any change in the community, usually accompanied by the disappearance of the proverbs which no longer fit with the circumstances that have changed. In the days that are no longer traditional, there are lots of values provided in proverbs that are still currently relevant. This means that these values can still be applied, even more is needed to bring the public back to the noble values. Proverbs is importantly needed to stem the new values that arise because of the modernization and globalization. Some of the relevant proverbs work under the supporting factors.

Reasons for the Javanese Community in ExSurakarta Use and Express the Javanese Proverbs which Summarize the Local Wisdom, as identified in the following paragraphs:

1. Cultural factors. The existence of the Javanese proverbs that summarize the local wisdom is an actuality due to the demands of practicing hereditary traditions which have been wellmaintained from generations. Culturally, the community live in Ex-residency of Surakarta realize their power as a central figure for the Javanese tradition. The ideas summarize in cultural terms such as memetri 'scrutinizing, compiling, paying attention, and nourishing' and nguri-uri 'preserving, maintaining' the Javanese language and culture which summarize local wisdom to able to be heard, written, followed, applied, and deemed as guidance to positive values in order to avoid negative values. Therefore, it is not surprising that the pioneers of the Javanese language and culture would take advantage of the available opportunities to express the Javanese proverbs that summarize local wisdom. This is done so 
in order the messages resided in the proverbs are significant for their lives, so that every member of the community could follow the positive instinct of their Javanese innateness.

2. Linguistics Factors. Javanese language as a medium of expressing the Javanese proverbs facilitate this, both in terms of the potential beauty of the language (Kawi language) and in terms of the depth and universality of the reaching messages, meaning, and enable to summarize the motivations of the practitioners. Among the motivations are (a) economical and practical motivations (encourage practitioners to earn money from the jobs), the motivation to show the potential skills of using language, (b) ideological motivation (to be able to convey important messages resided in the Javanese proverbs, the motivation to preserve the Javanese proverbs), and for any other reason. For the community, motivations that encourage them in expressing ideas with Javanese proverbs is essential meant to show their local knowledge (manners to overcome problems of their lives in rightly guided way and according to local traditions) by means of the beautiful aspects of the Javanese language (either in the forms of poems, poem and diction).

3. Aesthetical Factors. The use of the Javanese proverbs summarizes the local wisdom, because of the aesthetic demands (demands of expressing ideas through beautiful language). On using the Javanese language, most speakers (of Java) normally express their thoughts in beautiful language. These manners are often termed as ngrengga basa 'to decorate' a language and the type of such language use are termed as basa rinengga 'the decorated language', the language which is intentionally created to give a sense of beauty out of the use of the literary expressions and literature'. Therefore, in case any practitioners who have not yet been able to achieve such a degree, then aesthetically they are not yet qualified to the degree of understanding and having ability to speak the Javanese language beautifully, durung Jawa 'not able yet' (personal communication, Parmin et al., 2013) ${ }^{2}$. Like two sides of a coin, if the degree of using the Javanese language determined by memorizing patrap 'body language' and pangucap 'spoken language' and with unggah-ungguhing basa Jawa 'the Javanese speech levels'. If one has successfully fulfilled the Javanese speech levels and both rightly and properly use of dictions, then the beauty of the Javanese proverbs may increasingly reach a high degree of aesthetic.

4. Ethical factors. In addition to factors related to the cultural language, aesthetical aspects, the Javanese communities in Ex-residency of Surakarta still maintain the Javanese proverbs that summarize the local wisdom due to the demands on the ethical factors (the demand of showing polite expressions). The Javanese proverbs are expressed with a hope that the community can fulfill the ethical factors in communications. For example, promoting ideas could avoid direct confrontation between people in conflict, then the properly expressed Javanese proverb as expressed by Prabowo (Presidential Candidate in 2014) publically stated that becik ketitik ala ketara 'good will appear, so the evil' on accepting his situation of being a victim of his rival's fraudulent which led him into feeling dissatisfaction about the results of the presidential election of 2014 announced by KPU. Prabowo seemed to unwillingly extend the issue, so that he expressed the above Javanese proverbs to neutralize the situation and prevent for the forthcoming problems. Why did Prabowo express that Javanese proverb? Because his ancestral origin was from Javanese ethnic, especially who was originated from Banyumas. In addition, he also intended not to easily lose his anger which might at the end offend a group of people who opposed the political direction against his supporters.

5. Social factors. The use of the Javanese proverbs that summarize the local wisdom reflects the demands of social factors (of observing politeness in language use to maintain harmony, cohesiveness, mutual help, mong-kinemong 'maintain mutual respect', ngajeni 'honor'). Thus, the use of the Javanese proverbs is deemed to be important for the Javanese community in Ex-Surakarta to keep the atmosphere of the Java community who willingly advance harmony, cohesiveness, mutual help, mongkinemong 'maintain mutual respect', ngajeni 
'honor' (personal communication, Nuryani, et al, 2013)3. Why should be like that?, because the community still maintain the values of Javaneseness as reflected through the beauty of the language (catchy rhyme and in meaningful expressions), a realization to avoid possibility of communicating direct confrontation (kinds of expressions which employed figurative, metaphorical, by way of refracted, and connotative meanings and symbolic expressions as a strategic means of communication) on behalf of the local tradition (at any given time and situation, the Javanese language is distinctively expressed from one which is common and daily spoken language) it requires an atmosphere which leads them to be in-group on a certain time and even longer, therefore, one of the successful binders to increase social engagement is on an interesting use of the Javanese language, more exciting and lovely nuance (using the Javanese proverbs).

6. Economic Factors. Expressing the Javanese proverbs that summarize the local wisdom essentially followed by the demands of the economic factors (of the family income to maximally employ the Javanese language skills in serving people or the community in need). The existence of an individual or group of individuals who are associated with the motivations from which these economic factors emerged, in Ex-residency of Surakarta is vivid phenomenon and promising one, especially for those who engage with professional career or proficiency in beautifully use of the Javanese language and other professionalism such as being an $\mathrm{MC}$ in a wedding ceremonial process in Javanese tradition. Engaging with professional career as an MC in the Javanese tradition (pangendhaliwara, pamedhar sabda, paniti laksana, etc.), there are individuals who take it as a main professional career after retirement, or to deem it as a sideline career, or just being available in case any relative or family would ask for help in participating to resemble the agendas of a wedding ceremonial or other agendas related to the Javanese traditions (personal communication, Sutrisno, et al., 2013)

7. Political factors. Expressing the Javanese proverbs that summarize the local wisdom triggered by the demands of political factors which include other motivations such as cultural, linguistics, aesthetics, ethics and social factors (the demand of observing politeness in language use to maintain harmony, cohesiveness, mutual help, mongkinemong 'maintain mutual respect', ngajeni 'honor'). The important effects in expressing ideas through metaphorical language such as Javanese proverbs could soften the manners and build a better cooperation and avoid unstable emotion on using the language. The exemplification on the political factors concerning the use of Javanese proverbs occurred in the Indonesian presidential election in 2014 ago. When the nationalist Prabowo publically expressed a Javanese proverb, he strategically employed Javanese proverb to avoid any improper or sarcastic response that might trigger another great problem. Prabowo Djojohadikusomo (a presidential candidate of 2014) expressed a Javanese proverb becik ketitik ala 'good will appear, so the evil' to sincerely accept his trouble situation due to an unfair act and trait of his rival in the presidential election in 2014 regarding the results of the election announced by KPU (official commission of the Indonesian general election). Prabowo was unwilling to extend the issue; so alternatively he expressed the Javanese proverbs as a means of telling publically his desperate feelings and to remain discreet as a civil society. In addition, he did not want to pursue a continuing conflict that ultimately hurt the harmonious life of the societies.

8. Geographical Factors. Expressing the Javanese proverbs that summarize local wisdom motivated by geographical factors (place or ecology). When factors of culture, language, aesthetic, ethical, social deemed as an important consideration for Prabowo to express a Javanese proverb becik ketitik ala 'good will appear, so the evil' an expression to sincerely accept any trouble situation of any unfair act and trait of his rival. Prabowo personally aware of the role given by the Javanese proverbs as an alternative means of expressing feelings for the majority Javanese 
or listeners would automatically understood him. He was additionally aware of his rival ethnicity (Joko Widodo) with all his supporters as part of the Javanese community. The results of this study showed that when the Javanese proverbs are used to address any case, then the listeners should understand the ongoing context along with its high level use of dictions, then the desired proverbs could be aligned with the existing environment.

The Cultural Meanings of the Javanese Proverbs which summarize the local wisdom in Ex Surakarta, elaborated as follow:

Javanese proverbs that reflect the personal conducts (characters) of the pioneers whose act and saying contributed to the spirit of nationalism, among the Javanese proverbs are adus kringet 'sweat bathing' culturally illustrates spirit of struggling, working, earnest, never give up, unwilling to be always in dependency with others, persistent in achieving goals and keep maintaining them, unafraid of suffering from troubles and facing the trials. Hence the Javanese proverbs in relationship with the national spirit become an important capital. With that burning spirit, the Indonesian people will soon achieve their goals. The Javanese proverb wani mati 'daredevil' reflects a historical and nationalistic spirits of the Indonesian heroic figures. These heroic figures came from all parts of the Indonesian archipelagos. Therefore, it is highly expected that the next generations of the Indonesian people could inherit a daredevil spirit to defend their country and nation.

The Javanese proverbs that reflect personal conducts could sometimes be deemed as a barrier against nationalism, the Javanese proverbs such as mbukak wadi 'revealing one's secret'. This expression in accordance with intelligence and secret aspects of the country becomes a serious problem, because a personal character that unlocks the secrets (country, leaders of a country, etc.), shall weaken the strategy and the various interests of the Indonesian people.

Other life values summarize in the Javanese proverbs are actualized in the form of literary style (literary works) which imply significant moral messages as follow: (a) refine manners, for example on the Javanese proverbs manis eseme "(showing) a seductive smile' culturally is a potential characters that can be capital to communicate positively; momotatine 'patient' culturally reflect a wisdom of the Javanese life that indicates situational characteristic 'of a great soul'. (b) The integrity, moral strength and principle, for example wedi wirang 'fear of getting embarrassed' as a literary language which in everyday language expressed wedi isin 'fear of getting embarrassed' reflected messages of such expressions may contribute to a spirit of build characters of the Indonesian spirit of nationalism . The life experiences of the nation's predecessors remained an idea which indicates that wedi wirang as a literary language that can provide inspiration and spirit of the mental strength as well as to be self-prevention against carelessness and recklessness (personal communication, Hartini, et al., 2013) $)^{5}$. (c) the Javanese proverbs reflect empirical circumstance of the users' community, which additionally (1) reflect the nature of a great soul, for example lobokatine 'having tranquil heart' culturally reflect the Javanese local knowledge which is important to the national spirit; (2) reflect the spirit of moving forward, for example ngangsu kawruh 'seeking for knowledge' illustrates the willingness to gain more knowledge; (3) reflect the gentle nature and virtuous manners of the users, for instance on proverb menang tanpa ngasorake 'winning (something) on its right way/ showing enough appreciation, resolving problem in a peaceful way', being respectful towards each other and not to try to beaten, humiliated, and negatively perceived one another; (4) showing the attitude of avoiding bribery and women abuse, as expressed in a proverb ojo kengguh mring krincinging dhinar 'never easily get tempted to the gleaming of money / wealth', aja kengguh mring klubuking mina 'never easily be tempted to the moving curve of a fish, do not follow attitudes of the sycophants, "never try to obey the promptings of the bad persons', aja kengguh mring klimising wentis kuning' never easily get tempted to the beauty of the smooth legs (of women) (personal communication, 2013, Purwanto, et al., 2013 ${ }^{6}$ ); (5) showing the values of spirituality and consciousness in sacrificing, exemplified by a proverb jer basuki mawa bex vya 'success disserves a cost', yen dibeciki liyan tulisen jroning watu 'in case (someone) shares goodness write it on a stone', yen mbeciki liyan 
tulisen jroning lebu 'when (you) do good things to others, never try to remember them'; (6) showing life optimism about and being insightful, as expressed on a proverb jagad ora mung sagodhong kelor 'the world is bigger than a merunggai leaf', (personal communication, Sairin, et al ${ }^{7}$., 2013 (7) reflecting character that cannot be trusted and harming others, such as lunyu ilate "words that lack of trustworthiness' 'whose tongue does not always tell what his/her heart means/hypocrisy', gedhe endhase 'boastful, pompous, arrogant' metaphorically in the Javanese culture such Javanese proverbs reflect a message that a person who are claimed to have special authority, overability or social status tend to be more pretentious or to do something as pleasure, lack of respect toward others, (8) not showing a leadership character who should always be responsible for his/her act and words, as stated on a proverb mbukak wadi 'revealing one's secret', rai gedheg 'having a bit thick or never getting shame on (something)', ora katon dhadhane literally means 'never showing his own chest, 'unwilling to show his noble qualities, (personal communication, Suryanto et al. ${ }^{8}, 2013$ ) (9) reflecting a boastful character, showing off his/her special abilities, as stated on a proverb adigang, adigung, adiguna 'being over-proud for his/her social power, dignity and intelligence', asu gedhe kerahe 'powerful or big people will always be a winner at any social clash or court decision', (10) betrayal, as stated on a proverb mbukak wadi 'revealing one's secret', mbuang tilas' disposing a footstep, evidence, document', (11) amoral, as expressed rai gedheg 'having no shame'.

\section{CONCLUSION}

Based on the above finding data, the results of this study can be concluded as follow; factors underlying the use of Java proverbs expressed by the community in Ex-residency of Surakarta which summarize local wisdom (a) cultural factors, (b) linguistic factors, (c) aesthetical factors, (d) ethical factors, (e) social factors, (f) economical factors, (g) political factors, (h) geographical factors.

People in the Ex-residency of Surakarta express the Javanese proverbs that summarize the local knowledge which are additionally influenced by (a) cultural factors; (b) linguistic factors; (c) aesthetical factors; (d) ethical factors; (e) social factors; (f) economical factors; (g) political factors; and (h) geographical factors.

The cultural meanings reflected from the Javanese proverbs expressed by the community in Ex-residency of Surakarta that summarize the local wisdom, elaborated as follow; (a) the Javanese proverbs that reflect the personal conducts (characters) which contribute to the spirits of nationalism; (b) Javanese proverbs that reflect the personal conducts being deemed as a barrier against nationalism; (c) other life values in the Javanese proverbs are actualized in the forms of literary style (literary works), these refer to the meanings of (1) refining manners, (2) enhancing integrity, moral strength and life principles, (3) reflecting the empirical circumstances of the local community (such as reflecting the nature of great souls, reflecting the fighting spirit and persistency, reflecting the spirit of moving forward, reflecting the gentle nature and self-virtuousness, showing the attitude that against money bribery and women abuse, demonstrating the value of spirituality and consciousness to sacrifice, showing a life optimism and insightfulness, reflecting an unreliable and irresponsible characters and harming people, reflecting the social figure who are unnecessary to be followed, reflecting a personal trait of arrogant because of his/her achievement and social position, reflecting the real conducts of society in Ex-residency of Surakarta, having a realistic relationship with the heroic people (figures), philosophical relationship, satire (criticism), treason and amoral.

\section{REFERENCES}

Aggs-language. (October, 28 2016). "I love English language Sapir-Whorf Hypothesis". Retrieved from: https://aggslanguage.wordpress.com/ the-sapir-whorf-hypothesis/

Dove, Michael R., (1985), Peranan Kebudayaan Tradisional Indonesia dalam Modernisasi. Jakarta: Yayasan Obor

Mieder, W. (2004). Proverbs: A handbook. London: Greenwood Press.

Mahsun. (2005). “Konsep Ruang dalam Bahasa mBojo dan Kaitannya dengan Cara Pandang Masyarakat Penuturnya", dalam Linguistik Indonesia, Pebruari 2005, Th ke-23, No.1. 
Norrick, N.R. (1985). How proverbs mean? Semantic studies in English proverbs. Amsterdam: Mouton.

Rahyono, F.X. (2009). Kearifan Budaya dalam Kata, Jakarta: Wedatama Widyasastra.

Sartini, Ni Wayan. (2009). Menggali Nilai Kearifan Lokal Budaya Jawa Lewat Ungkapan (Bebasan, Saloka, dan Paribasa). LOGAT Jurnal Ilmiah Bahasa dan Sastra. No. 1 April 2009.

Sri Supiyarno, dkk., (2010).“Kearifan lokal orang Jawa yang tercermin dalam peribahasa Jawa (kajian Etnolinguistik)", Laporan Penelitian Dana DIPA FSSR UNS, Surakarta:Fakutas Sastra dan Seni Rupa Universitas Sebelas Maret.

Suharsini, Arikunto. (1993). Prosedur Penelitian Suatu Pendekatan Praktek, Jakarta: PT. Rineka Cipta.

Sutopo, HB., (2006) Metode Penelitian Kualitatif, Surakarta: Universitas Sebelas Maret Press.

Wakit Abdullah, et al., (2010). "Kearifan Lokal Petani di Pesisir Selatan Kebumen (Kajian Etnolinguistik)", Laporan Penelitian Hibah Fundamental, Surakarta: Fakutas Sastra dan Seni Rupa Universitas Sebelas Maret.

Wakit Abdullah, et al., (2011). "Bahasa Jawa dan Hubungannya dengan Perilaku Orang Jawa di Kota Surakarta", Laporan Penelitian Hibah Fundamental, Tahun I, Surakarta: Universitas Sebelas Maret.

Wakit Abdullah, et al., (2012). "Bahasa Jawa dan Hubungannya dengan Perilaku Orang Jawa di Kota Surakarta", Laporan Penelitian Hibah Fundamental, Tahun II, Surakarta: Universitas Sebelas Maret.
Wakit Abdullah, et al., (2013). "Kearifan lokal petani dan persepsinya terhadap pekerjaan non-petani di kabupaten Ngawi (Kajian Etnolinguistik)", Laporan Penelitian Hibah Madya, Dana BOPTN UNS 2013, Surakarta: Fakultas Sastra dan Seni Rupa Universitas Sebelas Maret.

Warnaen. (2001). Stereotip Etnis dalam Masyarakat Multietnis. Yogyakarta: Mata Bangsa.

\section{(ENDNOTES)}

1 Selected informant is a minimum requirement of five criteria; they are (1) the full enculturation, (2) direct involvement, (3) the unknown cultural atmosphere, (4) adequate time, and (5) a non-analytical (Spradley, 1997: 61).

2 Parmin HS. (65 years old), Sutrisno (56 years old) and Joko D. (50 years old) of Karanganyar regency, Jaten district

3 Mr. Dayat, SH. (50 years old), Mrs. Nuryani Amd. (40 years old), Drs. Ari Widiyanto (55 years old) of Wonogiri regency, Ngadirojo district

4 Sutrisno (45 years old), Arie Yulianto (30 years old), and Arisanti (40 years old) of Boyolali regency, Banyudono district.

5 Hartini, M. Hum (56 years old), Nanik Herawati (50 years old), Prembayun (35 years old) of Klaten regency, Klaten district

6 Purwanto (59 years old), Ari Wibowo (50 years old), Warsono (56 years old) of Sukoharjo regency, Mojolaban district

7 Sairin (70 years old), Widodo (56 years old), Ariyanti (57 years old) of Surakarta City, Jebres district.

8 Surynato (50 years old), Dr. Rahmanu W. (54 years old), Drs. Setyo Budi (57 years old) of Sragen regency, Karangmalang district. 